University of Nebraska - Lincoln

DigitalCommons@University of Nebraska - Lincoln

Nebraska Cooperative Fish \& Wildlife Research Nebraska Cooperative Fish \& Wildlife Research Unit -- Staff Publications

1997

\title{
EFFECTS OF RED IMPORTED FIRE ANTS ON RECRUITMENT OF WHITE-TAILED DEER FAWNS
}

Craig R. Allen

Texas Tech University, callen3@unl.edu

Stephen Demarais

Texas Tech University, steve.demarais@msstate.edu

R. Scott Lutz

Texas Tech University

Follow this and additional works at: https://digitalcommons.unl.edu/ncfwrustaff

Part of the Other Environmental Sciences Commons

Allen, Craig R.; Demarais, Stephen; and Lutz, R. Scott, "EFFECTS OF RED IMPORTED FIRE ANTS ON RECRUITMENT OF WHITE-TAILED DEER FAWNS" (1997). Nebraska Cooperative Fish \& Wildlife Research Unit -- Staff Publications. 48.

https://digitalcommons.unl.edu/ncfwrustaff/48

This Article is brought to you for free and open access by the Nebraska Cooperative Fish \& Wildlife Research Unit at DigitalCommons@University of Nebraska - Lincoln. It has been accepted for inclusion in Nebraska Cooperative Fish \& Wildlife Research Unit -- Staff Publications by an authorized administrator of DigitalCommons@University of Nebraska - Lincoln. 


\section{EFFECTS OF RED IMPORTED FIRE ANTS ON RECRUITMENT OF WHITE-TAILED DEER FAWNS}

CRAIG R. ALLEN,' Department of Range, Wildife, and Fisheries Management, Texas Tech University, Lubbock, TX 79409, USA STEPHEN DEMARAIS, Department of Range, Wildlife, and Fisheries Management, Texas Tech University, Lubbock, TX 79409, USA R. SCOTT LUTZ, ${ }^{2}$ Department of Range, Wildlife, and Fisheries Management, Texas Tech University, Lubbock, TX 79409, USA

Abstract: We investigated the effect of red imported fire ants (RIFA; Solenopsis invicta) on an index of whitetailed deer (Odocoileus virginianus) fawn recruitment (doe:fawn ratio) on 10 200-ha plots in the Texas Coastal Prairie during 1991-93. Five of the plots received treatments of the fire ant bait AMDROC (Am. Cyanamid Co., Wayne, N.J.) during April and October 1991 and May 1992 to reduce RIFA populations. The remaining 5 plots served as untreated comparison areas. Populations of RIFA were reduced $(P<0.10)$ on treated study areas during deer fawning periods in 1991-92. Fawn recruitment was higher on treated areas during $1991(P$ $=0.037)$ and $1992(P=0.069)$, with recruitment about twice as high on treated areas. In 1993 , after 1 year of RIFA reinfestation, fawn recruitment did not differ between treated and untreated plots $(P=0.443)$. We conclude that high density RIFA infestations reduced white-tailed deer fawn recruitment.

J. WILDL. MANAGE. 61(3):911-916

Key words: exotic insect, exotic species, fawn recruitment, invasive species, Odocoileus virginianus, red imported fire ants, RIFA, Solenopsis invicta, Texas Coastal Prairie, white-tailed deer.

Effects of the non-indigenous RIFA on large mammal populations have not been documented. However, the popular press has speculated on death and/or blinding of deer fawns by RIFAs (Grant and Killion 1988, Rollins 1989), and anecdotal evidence is abundant.

Evidence exists that suggests negative effects of the RIFA on other vertebrates (Allen et al. 1994). Predation by RIFAs was suggested as contributing to the decline of numerous reptiles (Mount 1981, Mount et al. 1981) and birds (Ridlehuber 1982, Sikes and Arnold 1986, Wilson and Silvy 1988). Recently, we documented greater northern bobwhite (Colinus virginianus) density on areas where RIFA populations were reduced, and reported a strong negative correlation between years of county-level infestation and northern bobwhite abundance in Texas (Allen et al. 1995). Individuals and communities of small mammals, such as cottontail rabbits (Sylvilagus floridanus; Hill 1969), pygmy mice (Baiomys taylori; Smith et al. 1990), and cotton rats (Sigmodon hispidus; Killion et al. 1990) may be affected by RIFAs.

The RIFA occuppied 101 million ha throughout the Southeast and Texas in 1985, and is ex-

\footnotetext{
1 Present address: Department of Wildlife Ecology and Conservation, 117 Newins-Ziegler Hall, University of Florida, Gainesville, FL 32611, USA.

2 Present address: Department of Wildlife Ecology, 1630 Linden Drive, 226 Russel Labs, University of Wisconsin, Madison, WI 53706, USA.
}

pected eventually to occupy about one-fourth of the United States (Vinson and Sorensen 1986). Monogynous, or single-queen, colonies of RIFA are territorial, with densities less than 100 mounds per ha. Polygynous, or multiple-queen, colonies lack intraspecific territoriality and typically occur at much greater densities, as high as 1,400 mounds per ha (Maxwell et al: 1982). In Texas, polygynous colonies constitute $>50 \%$ of all infestations (Porter et al. 1991). The spread of polygynous colonies, and increased awareness of their potential ecological disruption, have increased the interest in determining RIFA effects on indigenous species.

The economic value of white-tailed deer (Pope et al. 1984), coupled with anecdotal reports of deer fawn mortality (Rollins 1989) and concern for the community-level effect potential of polygyne RIFAs, led us to investigate the effect of the RIFA on white-tailed deer. Our objective was to document the effect of RIFA population reductions on white-tailed deer fawn recruitment in the Texas Coastal Prairie.

Funding was provided by American Cyanamid Inc., the Department of Plant and Soil Science at Texas Tech University, the Houston Livestock Show and Rodeo Association, Quail Unlimited, the Texas Department of Agriculture, the Texas Parks and Wildlife Department, the U. S. Department of Agriculture, and the Welder Wildlife Foundation. We thank F. C. Bryant, N. E. Mathews, M. Ortega, and G. Tan- 
ner for reviewing this manuscript. We thank S. Phillips, Jr. and $\mathrm{H}$. Thorvilson for cooperation on RIFA surveys, and the McFaddin Ranch, J. F. Welder Heirs, and P. H. Welder Ranch for allowing access to their properties. This is publication T-9-686 of Texas Tech University, College of Agricultural Sciences and Natural Resources, and 471 of the Rob and Bessie Welder Wildlife Foundation.

\section{STUDY AREA}

We worked in rangeland grazed by domestic cattle in 3 contiguous counties in the Coastal Prairie vegetational area of southeastern Texas (Gould 1975). Study areas were grouped into 5 paired plots (R1, R2, V1, VC1, and VC2), each about 200 ha $(\bar{x}=202$, range $=182-283)$. Pairing was based on similarity of soils, topography, vegetation, and pretreatment wildlife and RIFA indices (Allen 1993). Two plots were located in Calhoun County, 4 in Victoria County, and 4 in Refugio County. Nine plots were unimproved pasture; 1 (VC2 treated) had been overseeded with bermuda grass (Cynodon dactylon). The 4 plots in Refugio County were paired with each other (pairs R1 and R2). One pair was located in Victoria County (V1), and 2 pairs (VCl and VC2) had 1 member located in Victoria County and 1 in Calhoun County. Soils of pairs R1, R2, $\mathrm{V} 1$, and VCl were poorly-drained loams and clays with less than 3\% slope. Plots of pair VC2 bordered the Guadalupe River, and were rolling well-drained sandy loam.

Paired plots were separated by an average of $6.7 \mathrm{~km}$ (range $=3-14$ ) to maintain independence among replicates and treatments. We judged this distance to be sufficient to prevent significant deer movement among plots because white-tailed deer in this area seldom moved $>3.5 \mathrm{~km}$ during their lifetime (Michael 1965 , Ellisor 1969).

Land management practices varied among the 10 plots, but were similar within pairs. The R1, R2, VC1-untreated, and VC2-treated were open to hunting only by landowners and their guests, and deer harvest was low. Plots in Victoria County (V1-untreated, VC1-treated, VC2-untreated) were leased for recreational hunting; V1-treated was hunted by ranch personnel. The R1 and R2 plots were grazed continuously at the average stocking rate of 5.3 ha per cow. Other plots were grazed rotationally at various stocking rates. Variations in management practices within pairs were minimal and pear to produce habitat variations that potentially could have confounded the effect of RIFA treatments.

Climate was humid subtropical. Yearly average maximum and minimum temperatures for Victoria (central to all plots) were $27 \mathrm{C}$ and 16 C. Average yearly precipitation was $97 \mathrm{~cm}$ (Miller 1979).

Vegetation for all areas was a mixture of grasses, forbs, and varying amounts of brush. Brush foliar cover ranged from 7 to $40 \%$. Percent brush, grass, and forb species canopy cover on the plots may be found in Allen (1993).

\section{METHODS}

One randomly chosen member from each pair of plots was treated with AMDROC fire ant bait in April and October 1991, and May 1992 , at the average rate of $1.67 \mathrm{~kg} / \mathrm{ha}$. We chose AMDROC because it is fast-acting and regularly provides RIFA population reductions of $>75 \%$ for 6 months or more (Collins et al. 1991). We surveyed RIFA populations within 10 0.10-ha non-overlapping circular quadrats per plots, located near the center of each plot. This index method allowed for determination of treatment efficacy by incorporating data on mound density, ant population estimates within mounds, and the presence of fertile queens (Lofgren and Williams 1982). Populations of RIFA were surveyed pretreatment (Apr 1991), 7 times during treatments (between Jun 1991 and Aug 1992), and twice in the year following the cessation of treatments (Jun and Aug 1993).

We determined deer population composition with vehicular spotlight counts and incidental sightings collected on foot. We spotlighted deer in March 1991 (pretreatment) to estimate density only (Mitchell 1986). We conducted spotlight surveys in autumn 1991 from 1 September to 5 November, in 1992 from 1 September to 10 October, and in 1993 from 1 September to 13 November. Incidental observations were made on permanently established quail census transects (Allen et al. 1995), walked within 3 hours after sunrise and during the 3 hours before sunset from 1 . September to 30 October. An average of $55 \mathrm{~km}$ of transect was walked on each plot in both 1991 and 1992.

Spotlight counts began 15 minutes after dark, and ceased between 2300 and 0400 hours. We usually spotlighted members of a study area pair consecutively, and the order was switched with each repetition. Spotlight transects averaged 3.2 
Table 1. Average white-tailed deer densities (deer/100 ha) on 5 pairs of treated (TRT) and untreated (UNT) study areas in the Texas Coastal Prairie, before (spring 1991), during (fall 1991-92), and after (fall 1993) red imported fire ant reduction.

\begin{tabular}{|c|c|c|c|c|c|c|c|c|c|}
\hline \multirow[b]{3}{*}{ Pair } & & \multirow{2}{*}{\multicolumn{2}{|c|}{ Pretreatment 1991}} & \multicolumn{4}{|c|}{ Treatment } & \multirow{2}{*}{\multicolumn{2}{|c|}{ Posttreatment 1993}} \\
\hline & & & & \multicolumn{2}{|c|}{1991} & \multicolumn{2}{|c|}{1992} & & \\
\hline & & TRT & UNT & TRT & UNT & TRT & UNT & TRT & UNT \\
\hline \multirow[t]{2}{*}{$\overline{\mathbf{R} 1}$} & Density & 19 & 15 & 21 & 67 & 24 & 54 & 31 & 51 \\
\hline & $n^{a}$ & 2 & 2 & 3 & 3 & 7 & 7 & 7 & 7 \\
\hline \multirow[t]{2}{*}{$\mathbf{R} 2$} & Density & 16 & 15 & 67 & 24 & 73 & 14 & 72 & 9 \\
\hline & $n$ & 3 & 3 & 4 & 4 & 7 & 7 & 7 & 7 \\
\hline \multirow[t]{2}{*}{ Vl } & Density & 10 & 3 & 26 & 6 & 10 & 10 & 4 & 4 \\
\hline & $n$ & 2 & 2 & 7 & 11 & 10 & 10 & 9 & 9 \\
\hline \multirow[t]{2}{*}{ VCl } & Density & 3 & 13 & 6 & 17 & 15 & 27 & 8 & 14 \\
\hline & $n$ & 2 & 2 & 10 & 9 & 7 & 7 & 7 & 7 \\
\hline \multirow[t]{2}{*}{$\mathrm{VC2}$} & Density & 12 & 7 & 45 & 13 & 44 & 15 & 28 & 11 \\
\hline & $n$ & 2 & 2 & 8 & 9 & 7 & 7 & 7 & 7 \\
\hline \multirow[t]{4}{*}{ Means } & Density & 12 & 11 & 33 & 25 & 33 & 24 & 29 & 18 \\
\hline & $\mathrm{Se}^{\mathrm{b}}$ & 3 & 2 & 11 & 11 & 12 & 8 & 12 & 9 \\
\hline & $n$ & 2.2 & 2.2 & 6.4 & 7.2 & 7.6 & 7.6 & 7.4 & 7.4 \\
\hline & $P$-level ${ }^{\mathrm{c}}$ & \multicolumn{2}{|c|}{0.67} & \multicolumn{2}{|c|}{0.66} & \multicolumn{2}{|c|}{0.60} & \multicolumn{2}{|c|}{0.49} \\
\hline
\end{tabular}

"No. of spotlight repetitions.

b Standard error of density within treatments.

- Testing effect of treatments within sampling interval.

$\mathrm{km}$ within each 202-ha plot. Effective strip width was determined by measuring maximum visibility at $0.16 \mathrm{~km}$ intervals; average area of transect surveyed on each plot was $38 \mathrm{ha}$. We repeated individual spotlight transects 3 to 11 times; pairs with low density received more effort to increase the number of deer observed. Sex and age (i.e., fawn vs. adult) were determined at the time of observation. When sex and age of all members of a group could not be determined, these were not used in the determination of fawn recruitment (Mitchell 1986). Fawn:doe ratios (an index of recruitment) were calculated by pooling data from spotlight counts and transects. The total number of fawns observed on each plot was divided by the total number of does observed on each plot to yield estimated recruitment (fawns/doe; Mitchell 1986). Pretreatment surveys differed slightly in that fewer replications were used and the order of sampling was not grouped by pairings.

Estimated deer density and fawn recruitment were analyzed with randomized block design analysis of variance. We calculated Pearson correlations between RIFA indices and fawn recruitment in June 1991 and June 1992. We analyzed each sampling period independently because treatments were reapplied. Normality of data distribution was determined with the Shapiro-Wilk test (SAS Inst. Inc. 1989). Because of sample size limitations associated with spatially replicated field studies, differences between means were considered to have potential bio- logical significance at $P<0.10$ (Tacha et al. 1982). Each plot constituted an experimental unit, and results may be extrapolated to other similar areas.

\section{RESULTS}

Treatments with $\mathrm{AMDRO}^{\circ}$ fire ant bait were effective in reducing RIFA populations, especially during June (Jun 1991, $P=0.067$; Jun 1992, $P=0.062$; Allen et al. 1995), a time that coincides with white-tailed deer fawning periods (Halls 1978). Pretreatment RIFA indices averaged 435 and 297 per 0.10 -ha circle for treated and untreated plots. These indices corresponded to mound densities of 269 and 168 mounds per ha. Posttreatment indices averaged 60 on treated areas and 201 on untreated plots in June 1991, and 11 and 289 in June 1992. Treatment effects on RIFA populations are available in their entirety in Allen et al. (1995). In June 1993, 1 year after cessation of RIFA treatments, RIFA indices averaged 133 on treated plots and 252 on untreated areas, and did not differ statistically $(P>0.10 ; \mathrm{H}$. Thorvilson, Dep. Plant and Soil Sci., Texas Tech Univ., Lubbock, unpubl. data).

Deer density estimates varied among plots, but were not different between treated and untreated areas (Table 1). Densities were similar to those reported for the Texas Coastal Bend (Cook et al. 1971). Fawn recruitment estimates were not correlated significantly with June RIFA indices in $1991(r=-0.516, P=0.120$; 


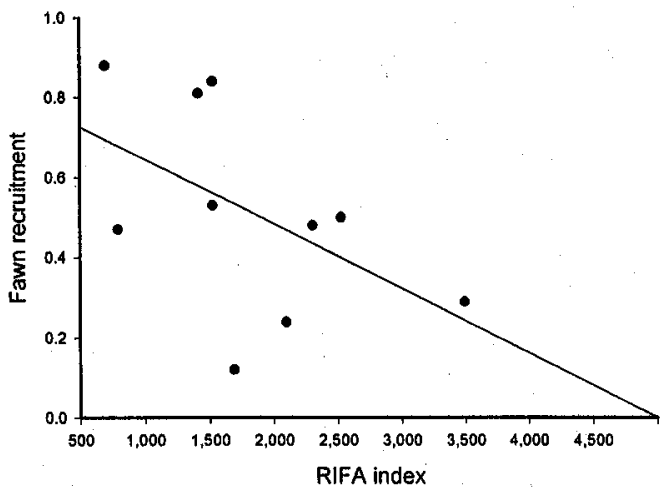

Fig. 1. Correlation between RIFA indices and estimated fawn recruitment, June 1991. $r=-0.516, P=0.12$.

Fig. 1), but were correlated negatively in 1992 ( $r=-0.650, P=0.042$; Fig. 2).

White-tailed deer fawn recruitment estimates were higher on treated plots than on untreated plots during $1991(P=0.037)$ and $1992(P=$ 0.069; Table 2). In 1991, recruitment estimates on treated plots averaged more than twice that of untreated plots. Estimated recruitment was lower on all areas during 1992, but recruitment on treated plots again was double that of untreated areas. In 1993, 1 year after the cessation of RIFA suppression, deer fawn recruitment did not differ $(P=0.443)$ between treated and untreated plots.

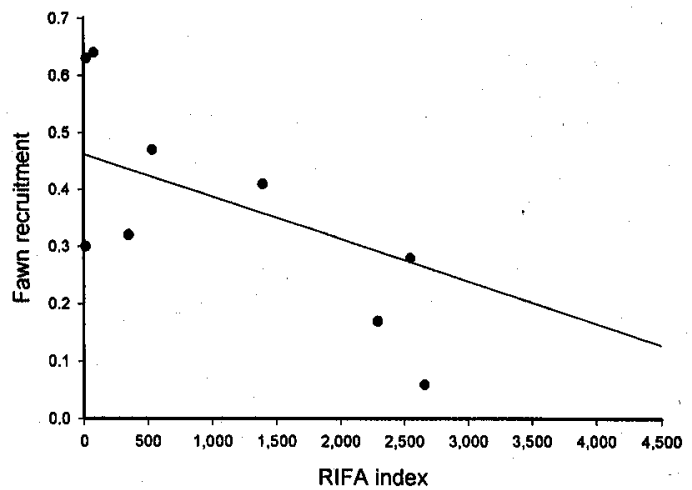

Fig. 2. Correlation between RIFA indices and estimated fawn recruitment, June 1992. $r=-0.650, P=0.04$.

\section{DISCUSSION}

Our results indicate that RIFA reduction has a positive effect on deer fawn recruitment in areas with high densities of polygynous ants. Higher fawn recruitment observed on treated areas was statistically and biologically significant despite the inherent low power associated with a design that employed 5 replications and 2 treatments (Lipsey 1990).

Lower RIFA mound densities on treated plots during June of 1991 and 1992 could have lessened the likelihood of contact between newborn white-tailed deer fawns and RIFAs. Decreased contact with RIFAs, and thus lower

Table 2. Effect of red imported fire ant population reductions on white-tailed deer fawn:doe ratios on 5 pairs of treated and untreated study areas in the Texas Coastal Prairie, 1991-92.

\begin{tabular}{|c|c|c|c|c|c|c|c|}
\hline \multirow[b]{2}{*}{ Pair } & \multirow[b]{2}{*}{ - } & \multicolumn{2}{|c|}{1991} & \multicolumn{2}{|c|}{1992} & \multicolumn{2}{|c|}{1993 Posttreatment } \\
\hline & & Treated & Untreated & Treated & Untreated & Treated & Untreated \\
\hline \multirow[t]{2}{*}{ R1 } & $n^{\mathfrak{a}}$ & 35 & 84 & 69 & 117 & 140 & 241 \\
\hline & Recruitment & 0.84 & 0.29 & 0.30 & 0.23 & 0.30 & 0.24 \\
\hline \multirow[t]{2}{*}{$\mathbf{R} 2$} & $n$ & 94 & 26 & 88 & 48 & 133 & 42 \\
\hline & Recruitment & 0.81 & 0.53 & 0.47 & 0.41 & 0.45 & 0.36 \\
\hline \multirow[t]{2}{*}{ V1 } & $n$ & 31 & 29 & 37 & 34 & 14 & 27 \\
\hline & Recruitment & 0.48 & 0.12 & 0.32 & 0.17 & 0.00 & 0.23 \\
\hline \multirow[t]{2}{*}{$\mathrm{VCl}$} & $n$ & 25 & 30 & 41 & 41 & 27 & 65 \\
\hline & Recruitment & 0.47 & 0.50 & 0.64 & 0.28 & 0.13 & 0.48 \\
\hline \multirow[t]{2}{*}{$\mathrm{VC} 2$} & $n$ & $77^{x+1}$ & 26 & 62 & 37 & 75 & 40 \\
\hline & Recruitment & 0.88 & 0.24 & 0.63 & 0.06 & 0.19 & 0.14 \\
\hline \multirow[t]{5}{*}{ Means } & Does ${ }^{b}$ & 30 & 30 & 41 & 45 & 60 & 65 \\
\hline & Fawns ${ }^{c}$ & 22 & 9 & 19 & 10 & 18 & 18 \\
\hline & Recruitment & 0.70 & 0.34 & 0.47 & 0.23 & 0.21 & 0.29 \\
\hline & $\mathrm{SE}^{\mathrm{d}}$ & 0.09 & 0.08 & 0.07 & 0.06 & 0.08 & 0.06 \\
\hline & $P^{\mathrm{e}}$ & 0.037 & & 0.069 & & 0.443 & \\
\hline
\end{tabular}

"Average no. of does and fawns observed, spotlighting and incidental.

b Average no. of does observed/plot.

- Average no. of fawns observed/plot.

d Standard error of fawn recruitment within treatments.

e Testing effect of treatments within sampling interval. 
rates of predation or injury, could explain the increased fawn recruitment on treated areas. We doubt that doe avoidance of areas with high RIFA mound density explains our results because does are faithful to fawning sites (Schwede et al. 1993), and does were present on untreated plots with high RIFA indices (Table 2). In addition, we doubt the development of such a specific population-level, behavioral response within the approximately 15 years since the 'non-indigenous RIFA first was observed in these counties.

Higher recruitment rates during 1991 were expected to increase deer densities on treated areas in 1992, but no increase was observed. However, deer density did not differ between treated and untreated areas during any time period tested (Table 1), whereas fawn recruitment was significantly higher on treated areas during 1991-92. Dispersal of yearling males (Tierson et al. 1985) and movement of yearling doe activity centers away from maternal activity centers (Hawkins and Klimstra 1970) may have prevented an increase in density on our relatively small, 202-ha plots.

Behavioral characteristics of RIFAs and deer fawns may influence the relation between these 2 species. The RIFA is attracted to mucous membranes such as the eyes and mouth (Vinson and Sorensen 1986), and recruit to food sources quickly and in large numbers. A neonatal fawn's defense to danger is to freeze (Ozoga et al. 1982), an inappropriate adaptation and ineffectual defense against RIFAs. Furthermore, frequent movement between bedding sites by fawns (Ozoga et al. 1982) increases the chance for contact with RIFA mounds or foraging trails, which may extend $40 \mathrm{~m}$ from a mound (Vinson and Sorensen 1986). Irritation from RIFA stings could lead to increased movement by fawns, and thus increase vulnerability to coyote (Canis latrans) predation. We hypothesize that the differences in recruitment on treated and untreated areas were the result of greater direct mortality of neonatal fawns by foraging RIFAs and indirect mortality by blinding, debilitating injury (Grant and Killion 1988, Rollins 1989), and higher coyote predation on untreated areas.

\section{MANAGEMENT IMPLICATIONS}

Recreational uses of white-tailed deer generate substantial economic benefits from direct and indirect sources. In Texas, economic benefits from white-tailed deer are especially high because of wide-spread lease hunting. Whitetailed deer hunting generated $\$ 210$ million per year for the Texas economy in the early 1980 s (Pope et al. 1984), and economic returns from deer may exceed returns from livestock (Ramsey 1965). In this study, white-tailed deer responded to the reduction of RIFA populations. An increase in deer harvest of 1 per square mile was estimated to enhance rural land value by $\$ 45.24$ per ha (Pope et al. 1984). The increased fawn recruitment observed in our study could provide additional harvestable white-tailed deer, provided there is no subsequent compensatory mortality and if the additional animals remain within the harvested population.

High density, polygynous RIFAs currently are sparsely scattered throughout the range of the RIFA, except in Texas where $>50 \%$ of all infestations are of the polygynous form (Porter et al. 1991). The expansion of the range of polygynous RIFAs, if it occurs, will undoubtedly increase the negative interaction between RIFAs and white-tailed deer.

More research is needed to determine the long-term effect of both polygyne and monogyne RIFAs on white-tailed deer populations. The threshold level of RIFA infestation that creates significant negative effects, if a threshold exists, must be determined. Our plots were infested primarily with polygyne RIFAs. Moderate and low density single-queen infestations presently account for the majority of infestations within the United States. Therefore, we need to determine if these effects also occur with monogyne RIFAs occurring at lower mound densities. We presently lack data on the exact mode of effect on deer, and the temporal variation in the degree of effect. Long-term research in a variety of habitats and regions needs to be initiated to further quantify the population-level effect of RIFAs on white-tailed deer and other native species.

\section{LITERATURE CITED}

ALLEN, C. R. 1993. Response of wildlife to red imported fire ant population reductions in the south Texas coastal prairie. M.S. Thesis, Texas Tech Univ., Lubbock. 153pp.

-—, S. DEMARAIS, AND R. S. LUTZ. 1994. Red imported fire ant impacts on wildlife: an overview. Tex. J. Sci. 46:51-59.

- , R. S. LUTz, AND S. Demarais. 1995. Red imported fire ant impacts on northern bobwhite popultions. Ecol. Appl. 5:632-638.

Collins, H. L., A. LADNER, A. CALlCOTT, T. LOCKLEY, AND L. MCANALLY. 1991. Seasonal effec- 
tiveness of Amdro ${ }^{\circ}$ and Logic ${ }^{\circ}$ for RIFA control. Pages 35-50 in M. E. Mispagel, ed. Proc. Imported Fire Ant Conf. Atlanta, Ga.

Cook, R. S., M. White, P. O. Trainer, and W. C. GLAZENER. 1971. Mortality of young whitetailed deer fawns in south Texas. J. Wildl. Manage. $35: 47-56$.

ELLISOR, J. E. 1969. Mobility of white-tailed deer in south Texas. J. Wildl. Manage. 33:220-222.

Gould, F. W. 1975. The grasses of Texas. Texas A\&M Univ. Press, College Station. 653pp.

Grant, W. E., AND M. J. KILLION, 1988. Impact of imported red fire ants on mammals. Pages 75-79 in The red imported fire ant: assessment and recommendations, Sportsmen Conserv. Texas, Austin.

Halls, L. K. 1978. White-tailed deer. Pages 43-65 in J. L. Schmidt and D. L. Gilbert, eds. Big game of North America ecology and management. Second ed. Stackpole Books, Harrisburg, $\mathrm{Pa}$.

HaWkINS, R. E., AND W. D. KLIMSTRA. 1970. A preliminary study of the social organization of whitetailed deer. J. Wildl. Manage, 34:407-419.

HiLL, E. P. 1969. Observations of imported fire ant predation on nestling cottontails. Proc. Annu. Conf. Southeast. Assoc. Game and Fish Comm. 23:171-181.

KILlion, M. J., W. E. Grant, AND S. B. Vinson. 1990. The influence of red imported fire ants (Solenopsis invicta) on small mammal habitat utilization. Pages 43-44 in M. E. Mispagel, ed. Proc. 1990 Imported Fire Ant Conf., Univ. Georgia, Athens.

LIPSEY, M. W. 1990. Design sensitivity: statistical power for experimental research. Sage Publ. Inc., Newbury Park, Calif. 207pp.

LOFGREN, C. S., AND D. F. Williams. 1982. Avermectin $B_{1} a$ : highly potent inhibitor of reproduction by queens of the red imported fire ant ( $\mathrm{Hy}$ menoptera: Formicidae). J. Econ. Entomol. 75: 798-803.

MaXwell, F. G., W. A. Banks, J. L. Bagent, W. L. Buren, O. Frank, S. Risch, A. Sorensen, W. L. Sterling, and J. L. Stimac. 1982. Population dynamics of the imported fire ant. Pages $67-72$ in S. L. Battenfield, ed. Proc. Symp. Imported Fire Ant. U. S. Dep. Agric., Atlanta, Ga.

MiCHAEL, E. D. 1965. Movements of white-tailed deer on the Welder Wildlife Refuge. J: Wildl. Manage, 29:44-52.

MILLER, W. L. 1979. Soil survey of Victoria county, Texas. U.S. Soil Conserv. Serv. 148pp.

Mitchell, W. A. 1986. Deer spotlight census: section 6.4.3. U.S. Army Corps Eng. Wildl. Res. Manage. Man. Tech. Rep. EL-86-53, Vicksburg, Miss. 2lpp.

Mount, R. H. 1981. The red imported fire ant, Solenopsis invicta, (Hymenoptera: Formicidae), as a possible predator of some native southeastern vertebrates: direct observations and subjective impressions. J. Ala. Acad. Sci. 52:71-78.

- S. E. Trauth, and W. H. Mason. 1981. Predation by the red imported fire ant, Solenopsis invicta (Hymenoptera: Formicidae), on eggs of the lizard, Cnemidophorus sexlineatus (Squamata: Teiidae). J. Ala. Acad. Sci. 52:66-70.

OzogA, J. J., L. J. Verme, AND C. S. BIENZ. 1982. Parturition behavior and territoriality in whitetailed deer: impact on neonatal mortality. J. Wildl. Manage. 46:1-11.

Pope, C. A. III, C. E. Adams, and J. K. Thomas. 1984. The recreational and aesthetic value of wildlife in Texas. J. Leisure Res. 16:51-60.

Porter, S. D., A. BhatKar, R. Mulder, S. B. VinSON, AND J. D. ClaIR. 1991. Distribution and density of polygyne fire ants (Hymenoptera: Formicidae) in Texas. J. Econ. Entomol. 84:866-874.

Ramsey, C. W. 1965. Potential economic returns from deer as compared with livestock in the Edwards Plateau region of Texas. J. Range Manage. 18:247-250.

RIDLEHUBER, K. T, 1982. Fire ant predation on wood duck ducklings and pipped eggs. Southwest. Nat. $27: 222$.

Rollins, D. 1989. Fire ants put heat on deer fawns. On the Wild Side 3:3

SAS INST. INC. 1989. SAS/STAT user's guide. Version 6. SAS Inst. Inc. Cary, N.C. 956pp.

SCHWEDE, G., H. HENDRICHS, AND W. MCSHEA. 1993. Social and spatial organization of female white-tailed deer, Odocoileus virginianus, during the fawning season. Anim. Behav. 45:1007-1017.

SIKES, P. J., AND K. A. ARNOLD, 1986. Red imported fire ant (Solenopsis invicta) predation on cliff swallow (Hirundo pyrrhonata) nestlings in eastcentral Texas. Southwest. Nat. 31:105-106.

SMITH, T. S., S. A. SMITH, AND D. J. SCHMIDLY. 1990. Impact of fire ant (Solenopsis invicta) density on northern pygmy mice (Baiomys taylori). Southwest. Nat. 35:158-162.

TACHA, T. C., W. D. WADE, AND K. P. BURnhaM. 1982. Use and interpretation of statistics in wildlife journals. Wildl. Soc. Bull. 10:355-362.

Tierson, W. C., G. F. Mattfeld, R. W. Sage, JR, AND D. F. BEHREND. 1985. Seasonal movements and home ranges of white-tailed deer in the Adirondacks. J. Wildl. Manage. 49:760-769.

VINSON, S. B., AND A. A. SORENSEN. 1986. Imported fire ants: life history and impact. Texas Dep. Agric., Austin. 28pp.

WILSON, D. E., AND N. J. SILVY. 1988. Impact of the imported fire ants on birds. Pages 70-74 in The red imported fire ant: assessment and recommendations. Sportsmen Conserv. Texas, Austin.

Received 29 November 1995.

Accepted 4 February 1997.

Associate Editor: Hobbs. 